\title{
Activity of chitosan films enriched with the essential oil of Alpinia malaccensis rhizome against $S$. aureus, $E$. coli and $C$. musae
}

\author{
P.A.S.R. Wickramarachchi*, I.N. Samaratunge, C.H.T.C. Kaushalya, W.P.M. Rasangika and \\ P.A. Paranagama \\ Department of Chemistry, Faculty of Science, University of Kelaniya, Kelaniya.
}

\begin{abstract}
In this paper, the in vitro antimicrobial activity of Alpinia malaccensis rhizome oil was investigated in its pure form and incorporated into chitosan films, against Colletotrichum musae, Staphylococcus aureus and Escherichia coli. Dry rhizome oil of A. malaccensis was extracted using steam distillation. Chitosan films enriched with the oil were prepared by casting as a potential bio-based food packaging film. The major constituent of A. malaccensis oil was identified as 1,8-cineole by GC-MS. The antifungal activity of the essential oil (EO) was tested using the disk diffusion method. The minimum inhibitory concentration (MIC) and the minimum lethal concentration (MLC) for C. musae was 100.0 and $300.0 \mu \mathrm{g} \mu \mathrm{L}^{-1}$, respectively. A liquid bioassay method was used to determine the antifungal efficacy of the oil enriched chitosan films against $C$. musae. More than $50 \%$ inhibition of the growth of the fungus was achieved when the oil concentrations in EO-chitosan films was between $0.08-0.40 \mu \mathrm{g} \mathrm{m^{-2 }}$. The antibacterial activity of the oil and the oil enriched films was determined by measuring the optical density of the cultures at $610 \mathrm{~nm}$. The optical density $\left(\mathrm{OD}_{610}\right)$ values of $S$. aureus and E. coli cultures showed a sharp and gradual reduction, respectively with increasing oil concentration. The growth of $S$. aureus was negligible at oil concentrations higher than $5.0 \mu \mathrm{g} \mu \mathrm{L}^{-1}$. The oil enriched films showed a lower inhibition of the growth of both bacteria.
\end{abstract}

Keywords: Alpinia malaccensis, antibacterial activity, Colletotrichum musae, Escherichia coli, essential oil, Staphylococcus aureus.

\section{INTRODUCTION}

Quality and safety are the major concerns in the food industry. The consumer prefers fresh and minimally processed food. Antibacterial sprays, dips and conventional packaging material such as polythene and their derivatives have been used to overcome spoilage of food. However, there are some limitations in direct surface application of antibacterial substances since the active substances could be neutralised, evaporated or diffused inadequately into the bulk of the food. Although plastics and their derivatives are effective in food preservation, they contribute towards environmental pollution. Hence, there is an urgent demand for packaging materials, which are more economical and environmentally friendly. An edible coating or a film could be defined as a primary packaging made from edible components. In this process a thin layer of edible material is directly coated or formed into a film and used as a food wrap without changing the original ingredients or the processing method. Edible films and coatings have been used to improve gas and moisture barriers, mechanical properties, sensory perceptions, convenience, and microbial protection and also to prolong the shelf life of various products. Edible bio-based films have been investigated for their ability to avoid moisture loss or water absorption by the food material, oxygen penetration into the food material and solute transports. This is one of the most effective methods to maintain food quality. The major advantage of edible films and coatings is the ability to incorporate active ingredients such as antioxidants, antimicrobial agents, colourants, flavours, fortified nutrients and spices into the polymer matrix thus enhancing safety or even nutritional and sensory attributes. A comprehensive review by RojasGraü et al. (2009) discusses the use of edible coatings as carriers of functional ingredients on fresh-cut fruits.

One of the most effective bio-based packaging films can be made using chitosan. The deacetylation of chitin, a structural component of the exoskeleton of crustaceans, 
results in chitosan. It is a biodegradable waste product from the sea food industry and safe for consumption as it is nontoxic to mammals (Chien \& Chou, 2006). Usage of chitosan as a food packaging film has many advantages compared to the other edible films because of its antibacterial activity and metal chelation properties, which partly contribute towards the antimicrobial activity by chelating metal ions that are essential for bacterial growth. The applications of chitosan for the improvement of quality and shelf life of various agricultural, poultry and marine foods have been comprehensively reviewed (No et al., 2007). The incorporation of various natural extracts such as green tea extract, grapefruit seed extract and essential oil (EO) into chitosan films, and their antimicrobial activities have been reported (Han, 2013). Many studies incorporating essential oils from various plants such as tea, bergamot (Sanchez-Gonzalez et al., 2010a; b), cinnamon (Xing et al., 2011) and thymus (Mehdizadeh et al., 2012) have been reported. The antimicrobial activity of various crude extracts of several Alpinia species (Zingiberaceae), A. Galanga (Rao et al., 2010) and A. officinarum (Srividya et al., 2010) have been proved. However, there is no published information on the antimicrobial activity of $\mathrm{EO}$ from $A$. malaccensis (Burm. f.) Roscoe (Zingiberaceae) rhizome, or an attempt to incorporate this oil into chitosan films to be used as an antimicrobial packaging.

During this study the antibacterial activity of EO from A. malaccensis rhizome and the oil incorporated chitosan films against Colletotrichum musae, Staphylococcus aureus and Escherichia coli was determined.

A. malaccensis is a perennial herb grown in Sri Lanka, containing rhizomatous rootstocks and leafy stems. The rhizomes are used to cure wounds and sores and chewed together with betel nut to make the voice strong and clear. The essential oil extracted from the rhizomes of $A$. malaccensis species grown in Thailand contains 1,8-cineole $(11.9 \%)$ as the major component followed by linalool $(9 \%)$ and fenchyl acetate $(8.6 \%)$ (Pripdeevech et al., 2009), whereas the major constituent of A. malaccensis rhizomes collected from Malaysia is methyl cinnamate (Azah et al., 2005). However A. bundiflora Burtt \& Smith, A. fox Burtt \& Smith (endemic to Sri lanka) and A. nigra (Gaertn.) Burtt collected from Sri Lanka did not show any antibacterial activity (Hewage et al., 1998).

The genus Colletotrichum is considered to be one of the major plant pathogens, which causes anthracnose disease (Abd-Elsalam et al., 2010). Colletotrichum musae causes major damage to banana in the postharvest stage. Anthracnose and crown rot are the main postharvest diseases affecting the quality of exported bananas (Postmaster et al., 1997; Lim et al., 2002; Ranasingha et al., 2002; Abd-Elsalam et al., 2010). Anthracnose infection is characterised by dark, sunken lesions. Crown rot is caused by a fungi complex involving C. musae and Lasiodiplodia theobromae (de Lapeyre \& Mourichon, 1998; Krauss et al., 2001; Ranasingha et al., 2002). With crown rot, a brown to black colour develops on the 'crown' where the hands are severed from the bunch. The fingers may detach prematurely from severely infected crowns and the disease may increase rapidly during fruit ripening.

Staphylococcus aureus is a Gram positive bacterium, which is a circular (cocci) shaped facultative anaerobe. S. aureus produces yellow pigmented colonies and some characteristics of $S$. aureus account for their pathogenicity. It is able to grow in food with high osmotic pressure or in low moisture food that tend to inhibit the growth of other organisms. Escherichia coli is a Gram negative bacterium, which is a rod shaped, facultative anaerobe and belongs to the Enterobacteriaceae family. E. coli is commonly found in the gut of humans and warm blooded animals. Although most strains of $E$. coli are harmless, some strains such as enterohaemorrhagic E. coli can cause severe food borne diseases, urinary tract infections and respiratory illnesses.

\section{METHODOLOGY}

\section{Collection of plant materials and extraction of essential oil}

A. malaccensis rhizomes were collected from plants grown in Sri Lanka and the plant was authenticated at the Navinna Herbal Gardens, Sri Lanka. The rhizomes were washed to remove mud, cut into small pieces and air dried for 3 days. The air dried pieces $(500 \mathrm{~g})$ were steam distilled and the distillate was extracted with dichloromethane. The dichloromethane layer was dried using anhydrous $\mathrm{Na}_{2} \mathrm{SO}_{4}$ and the fractions of dried dichloromethane were evaporated using a rotary evaporator (R-114 \& B-480, Büchi Labortechnik AG, Flawil, Switzerland) at $35^{\circ} \mathrm{C}$. Nitrogen was purged through the sample to remove any remaining solvent.

\section{Identification of the constituents of EO using GC and GC/MS}

The constituents of the essential oil of $A$. malaccensis rhizomes were identified using gas chromatography (GC) (6890 series; Hewlett Packard, Palo Alto, CA, USA) - mass spectrometry (MS) (5973 series, Hewlett Packard, Palo Alto, CA, USA). The GC conditions used were $5 \%$ 
phenylmethylsiloxane column (Hewlett Packard, Palo Alto, CA, USA), carrier gas He, column temperature programme: $60{ }^{\circ} \mathrm{C}$ for $1 \mathrm{~min}$ and then heated to $240^{\circ} \mathrm{C}$ at a rate of $40^{\circ} \mathrm{C}$ $\mathrm{min}^{-1}$ and again heated to $300{ }^{\circ} \mathrm{C}$ at a rate of $15{ }^{\circ} \mathrm{C} \mathrm{min}^{-1}$. The constituents of the essential oil were identified using search libraries, Wiley 275.L and Nist 98.1.

\section{Maintenance of fungal cultures and antifungal bioassay}

Potato dextrose agar (PDA) was sterilised in an autoclave at $121{ }^{\circ} \mathrm{C}$ for $30 \mathrm{~min}$ (Sterilemax, Series 1118, Barnstead Thermolyne, Duduque, IA, USA) and the Petri dishes were sterilised in an oven at $180{ }^{\circ} \mathrm{C}$ for $3 \mathrm{hrs}$. Seven days old fungi cultures were used to make the spore inoculum. A series of concentrations $50.0-500.0 \mu \mathrm{g} \mu \mathrm{L}^{-1}$ of essential oil was prepared. Antifungal activity of the rhizome essential oil was determined using the disc diffusion method. Each concentration was replicated 4 times. The plates were sealed and incubated for 3 days at room temperature $\left(28 \pm 2{ }^{\circ} \mathrm{C}\right)$. A positive control (Bavistine, $50.0 \mu \mathrm{g} \mu \mathrm{L}^{-1}$ ) and a negative control (DMSO, $\left.50 \mu \mathrm{g} \mu \mathrm{L}^{-1}\right)$ were also tested. The minimum inhibitory concentration (MIC or the fungistatic concentration) and the minimum lethal concentration (MLC or the fungicidal concentration) of the essential oil against $C$. musae were determined.

\section{Maintenance of bacterial cultures and antibacterial bioassay}

For the antibacterial activity test, $S$. aureus (ATCC 25923) and $E$. coli (ATCC 25922) from the culture collection of the Department of Microbiology, University of Kelaniya, Sri Lanka was used. The test bacterial cultures were grown on nutrient agar slants and kept at $4{ }^{\circ} \mathrm{C}$. Nutrient broth (meat peptone $4.3 \mathrm{gL}^{-1}$, Lasen peptone $4.3 \mathrm{gL}^{-1}$, $\left.\mathrm{NaCl} 6.4 \mathrm{gL}^{-1}, \mathrm{pH} 7.5\right)(0.65 \mathrm{~g})$ was dissolved in distilled water $(50.0 \mathrm{~mL})$ and autoclaved at $121{ }^{\circ} \mathrm{C}, 15$ psi for 30 min (Sterilemax, Series 1118, Barnstead Thermolyne, Duduque, IA, USA). A loopful of bacteria from the agar slant was taken and inoculated into $50.0 \mathrm{~mL}$ of the nutrient broth in a $100.0 \mathrm{~mL}$ flask to prepare the seed cultures. The flask was then incubated at $125 \mathrm{rpm}$ in an incubator at $37{ }^{\circ} \mathrm{C}$ for $24 \mathrm{hrs}$. A dilution series was prepared to meet the required bacterial population for seeding by using sterile distilled water.

Antibacterial activity of rhizome oil of A. malaccensis against $E$. coli and $S$. aureus

A series of concentrations $\left(1.2-20.0 \mu \mathrm{g} \mu \mathrm{L}^{-1}\right)$ of the essential oil of $A$. malaccensis was prepared in $100.0 \mathrm{~mL}$ conical flasks. In order to carry out the antibacterial assay, each conical flask containing $50.0 \mathrm{~mL}$ of nutrient broth was mixed with $0.1 \mathrm{~mL}$ inoculum containing

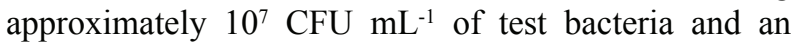
appropriate amount of the essential oil. The flasks were then incubated at $37^{\circ} \mathrm{C}$ for $24 \mathrm{hrs}$ and the $\mathrm{OD}_{610}$ of each sample was measured. Three replicates of each concentration were carried out. The antibacterial assay was carried out for $S$. aureus and E. coli, separately.

\section{Preparation of chitosan films}

Chitosan films were prepared using the method described by Ojagh et al. (2010). Distilled water was added to the control films instead of essential oil of A. malaccensis. Films formed were air dried for $72 \mathrm{hrs}$ at room temperature $\left(28 \pm 2{ }^{\circ} \mathrm{C}\right)$. The dried films were peeled off and stored under ambient conditions.

\section{Antimicrobial effects of chitosan films incorporated with $A$. malaccensis essential oil}

Yeast extract $(7.0 \mathrm{~g}), \mathrm{KNO}_{3}(1.5 \mathrm{~g})$, sucrose $(20.0 \mathrm{~g})$ and $\mathrm{MgSO}_{4} \cdot 7 \mathrm{H}_{2} \mathrm{O}(0.5 \mathrm{~g})$ were dissolved in $1 \mathrm{~L}$ of distilled water to prepare a semi-synthetic liquid medium (SMKY) to perform antifungal liquid bioassays. The SMYK medium $(25.00 \mathrm{~mL})$ was inoculated with C. musae fungal discs $(5 \mathrm{~mm})$ and chitosan films containing $0.00-0.40 \mu \mathrm{g} \mathrm{mm} \mathrm{mm}^{-2}$ of essential oil. The contents were mixed and placed on a shaker for 7 days at room temperature $\left(28 \pm 2{ }^{\circ} \mathrm{C}\right)$. The mycelium was recovered on to a pre-weighed filter paper, washed 3 times with sterile distilled water and placed in a hot air oven (Gallenkamp, serial No.SG97104/04/029-13A) at $70{ }^{\circ} \mathrm{C}$ overnight until a constant weight was obtained. Percentage inhibition of the growth of $C$. musae was determined using a method described by Jinasena et al. (2011).

Chitosan films containing the dry rhizome oil of A. malaccensis at levels of $0.000-0.028 \mu \mathrm{g} \mathrm{mm} \mathrm{mm}^{-2}$ were placed in sterilised conical flasks $(100.0 \mathrm{~mL})$ containing nutrient broth. $S$. aureus and E. coli cultures $\left(10^{7} \mathrm{CFU} / \mathrm{mL}\right.$, $100.0 \mu \mathrm{L}$ ) were inoculated into each flask separately. The samples were incubated overnight at $28( \pm 2)^{\circ} \mathrm{C}$. The $\mathrm{OD}_{610}$ of the samples were measured at the end of the incubation period.

The samples without chitosan films served as the control in both assays.

\section{RESULTS}

On steam distillation $A$. malaccensis rhizomes yielded a pale yellow colour oil with a strong odour. The percentage yield of the essential oil was $0.5 \%$. Twenty 
eight compounds were identified as present in the essential oil using GC-MS. The major constituent of the oil was 1,8 -cineole $(31.96 \%)$ followed by $\alpha$-terpinene $(17.78 \%)$, fenchyl acetate $(14.98 \%)$ and o-Cymene $(8.76 \%)$. Several other terpenes were also found to be present in trace amounts (Table 1).

Table 1: Major constituents in A. malaccensis rhizome essential oil

\begin{tabular}{lc}
\hline Constituent & Percentage $(\%)$ \\
\hline 1,8-Cineole & 31.96 \\
$\alpha$-Terpinene & 17.78 \\
Fenchyl acetate & 14.98 \\
o-Cymene & 8.76 \\
$\alpha$-Terpinolene & 4.19 \\
$\beta$-Pinene & 3.63 \\
dl-Limonene & 2.56 \\
Caryophyllene & 1.83 \\
Terpineol & 1.67 \\
Borneol & 1.05 \\
Bornyl acetate & 0.91 \\
\hline
\end{tabular}

Table 2: Mean average diameter of the inhibition zones of $C$. musae against A. malaccensis oil

\begin{tabular}{cc}
\hline $\begin{array}{c}\text { Concentration } \\
\text { of the oil }\left(\mu \mathrm{g} \mu \mathrm{L}^{-1}\right)\end{array}$ & $\begin{array}{c}\text { Diameter of inhibition } \\
\text { zone }(\mathrm{cm})^{*}\end{array}$ \\
\hline 50.0 & No inhibition \\
100.0 & $1.23( \pm 0.04)^{\mathrm{a}}$ \\
150.0 & $1.73( \pm 0.06)^{\mathrm{b}}$ \\
200.0 & $2.03( \pm 0.11)^{\mathrm{c}}$ \\
250.0 & $2.33( \pm 0.10)^{\mathrm{d}}$ \\
300.0 & $4.97( \pm 0.06)^{\mathrm{e}}$ \\
350.0 & $5.00( \pm 0.10)^{\mathrm{e}}$ \\
400.0 & $4.96( \pm 0.05)^{\mathrm{e}}$ \\
450.0 & $4.96( \pm 0.15)^{\mathrm{e}}$ \\
500.0 & $4.97( \pm 0.06)^{\mathrm{e}}$ \\
$(-)$ Control & No inhibition
\end{tabular}

\footnotetext{
* Mean of four replicates. Data are presented as mean \pm SD. Mean followed by different letters in superscript are significantly different from each other (ANOVA, Tukey's test, $\mathrm{p}<0.05$ ).
}

A. malaccensis rhizome oil was fungistatic and fungicidal against $C$. musae at 100.0 and $300.0 \mu \mathrm{g} \mu \mathrm{L}^{-1}$ concentrations, respectively (Table 2). No inhibition zone for the test pathogen was observed at $50.0 \mu \mathrm{g} \mu \mathrm{L}^{-1}$ oil concentration and the growth of C. musae was similar to that of the (-)ve control. The mean diameters of inhibition zones were significantly different at oil concentrations 150, 200 and 250 $\mu \mathrm{g} \mu \mathrm{L}^{-1}$. There was no significant difference between the treatments in the concentration range $300.0-500.0 \mu \mathrm{g} \mu \mathrm{L}^{-1}$ $(\mathrm{p}<0.05)$. Growth inhibition of the liquid bacterial culture by $A$. malaccensis essential oil was investigated by measuring the optical density of the broth cultures at $610 \mathrm{~nm}\left(\mathrm{OD}_{610}\right)$. Figure 1 presents the in vitro antibacterial effect of the test oil against $S$. aureus and E. coli. When the concentration of the test essential oil increased from 1.2 to $20 \mu \mathrm{g} \mu \mathrm{L}^{-1}$, the optical density at $610 \mathrm{~nm}$ decreased. The essential oil showed a significant antibacterial activity against $S$. aureus and a similar trend was observed for the optical density of the liquid culture of E. coli. However, the Gram-positive bacteria, $S$. aureus was more sensitive to the test oil than E. coli. Therefore the growth inhibition of $S$. aureus was significantly higher $(\mathrm{p}<0.05)$ compared to that of E. coli. The growth of $S$. aureus was negligible at concentrations higher than $5.0 \mu \mathrm{g} \mathrm{L}^{-1}$ as depicted by $\mathrm{OD}_{610}$ values of the broth cultures.

The in vitro antifungal activity of the test essential oil incorporated chitosan films against the aforementioned fungus was assessed qualitatively and quantitatively using the liquid bioassay method. According to the results presented in Table 3 , the liquid bioassay on the activity of EO-chitosan film against $C$. musae showed a considerable percentage inhibition of the pathogen at all concentrations, with increasing activity with increasing oil concentration in the film. The treatment containing the chitosan film without test essential oil also showed a $44 \%$ inhibition of the growth of fungi. There was a significant difference in percentage inhibitions by the oil incorporated films and the chitosan film without oil.

Table 3: Percentage inhibition of C. musae by chitosan films enriched with A. malaccensis oil

\begin{tabular}{cc}
\hline $\begin{array}{c}\text { Concentration of } \\
\text { oil in the film } \\
\left(\mu \mathrm{g} \mathrm{mm}^{-2}\right)\end{array}$ & $\begin{array}{c}\text { Percentage } \\
\text { inhibition* }\end{array}$ \\
\hline 0.00 & $43.9( \pm 1.7)^{\mathrm{a}}$ \\
0.08 & $53.2( \pm 1.8)^{\mathrm{b}}$ \\
0.16 & $55.0( \pm 1.6)^{\mathrm{b}}$ \\
0.24 & $54.8( \pm 1.5)^{\mathrm{b}}$ \\
0.32 & $62.0( \pm 1.7)^{\mathrm{c}}$ \\
0.40 & $69.8( \pm 1.6)^{\mathrm{d}}$ \\
Control & 0.0 \\
\hline
\end{tabular}

*Mean of four replicates. Data are presented as mean \pm SD. Mean followed by different letters in superscript are significantly different from each other (ANOVA, Tukey's test, $\mathrm{p}<0.05$ ). 


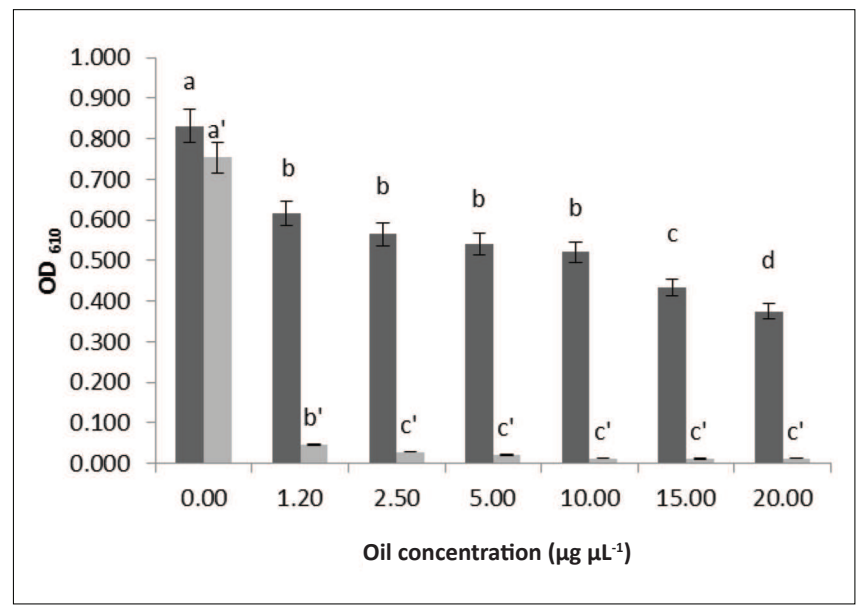

Figure 1: Graph of $\mathrm{OD}_{610}$ values of nutrient broth cultures of E. coli ( $\square$ ) and S. aureus ( $\square$ ) vs A. malaccensis rhizome oil concentration $(\mathrm{n}=3)$. Data are presented as mean \pm SD. The bars with different superscript letters are significantly different from each other (ANOVA, Tukey's test. $\mathrm{p}<0.05$ ).

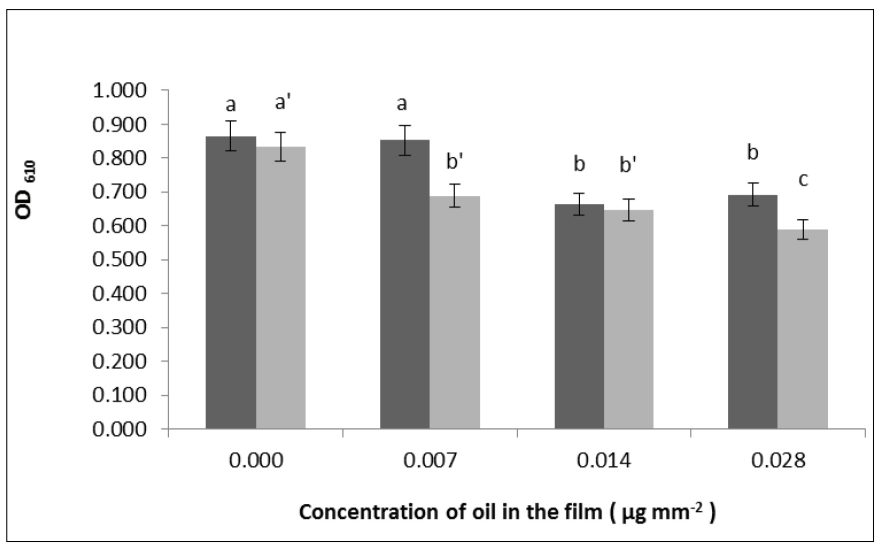

Figure 2: Graph of $\mathrm{OD}_{610}$ values of nutrient broth cultures of $E$. coli ( $\square$ ) and S. aureus ( $\square$ ) vs concentration of $A$. malaccensis rhizome oil in chitosan films $(\mathrm{n}=3)$. Data are presented as mean \pm SD. The bars with different superscript letters are significantly different from each other (ANOVA, Tukey's test. $\mathrm{p}<0.05$ ).

The percentage inhibition increased significantly when the oil concentration in the film was increased in the range 0.08 to $0.40 \mu \mathrm{g} \mathrm{mm}^{-2}(\mathrm{p}<0.05)$.

In order to study the antibacterial activity of chitosan films enriched with the test essential oil, in vitro antibacterial activity was assessed by measuring the optical density at $610 \mathrm{~nm}$. The growth inhibition of $S$. aureus and E. coli by EO-chitosan films are shown in Figure 2. A gradual decrease of $\mathrm{OD}_{610}$ values was observed for $S$. aureus and E. coli with increasing oil concentration in the film $(0.007$ $0.028 \mu \mathrm{g} \mathrm{mm}^{-2}$ ). However, the inhibition of $S$. aureus was lower when the oil was incorporated into the film than the inhibition shown when the oil was directly introduced to the assay medium (Figures 1 and 2). 


\section{DISCUSSION}

Chemical composition of the essential oil of A. malaccensis rhizome varies depending on the geographical distribution and ecological conditions. The major constituent of A. malaccensis rhizome oil from Bangladesh (29.9\%) and Thailand (11.9\%) was 1,8-cineole (Postmaster et al., 1997). In Malaysia and India it was methyl cinnamate (85.7 \%) (Azah et al., 2005). The EO of $A$. galanga and $A$. calcarata rhizomes from Sri Lanka contained 1,8-cineole as the major component (Paranagama \& Ekanayake, 2004; Arambewela et al., 2007).

Many plant derived essential oils have shown natural antifungal, insecticidal, antimicrobial, and antioxidant properties. For example, the EO of several species of Rutaceae have exhibited potent antibacterial activity (Bandara et al., 1990). Due to these characteristics, essential oils have gained much attention in food and agriculture sector as a potential antimicrobial agent of natural origin. The United States Food and Drug Administration (USFDA) (1997) classifies essential oils as 'Generally Recognised As Safe (GRAS)' compounds and includes clove, oregano, nutmeg, thyme, basil, mustard and cinnamon (Han, 2013). Essential oils from the cinnamon leaf (Cinnamomum zeylanicum), citronella (Cymbopogon nardus), lemongrass (Cymbopogon citratus) and wild sprang (Micromelum minutum) have indicated insecticidal and antifungal activities (de Lapeyre \& Mourichon, 1998; Ranasingha et al., 2002).

Chitosan films without the essential oil were also inhibitory of the test pathogens due to the inherent antimicrobial properties of chitosan. However an enhanced activity of the films was observed when the films were enriched with A. malaccensis oil. The inhibition of the growth of $S$. aureus by the oil was higher than that of E. coli. Generally essential oils are more active against Gram positive bacteria compared to Gram negative bacteria. The different susceptibilities of E. coli (Gram negative) and S. aureus (Gram positive) to the oil may be due to the different compositions of their cell walls. E. coli possesses an outer membrane, which restricts the passage of compounds into the cell. S. aureus is deprived of an outer membrane and compounds can easily migrate in, disrupting the functions of the cell (Ming et al., 2010). The growth of $S$. aureus and $E$. coli has been significantly inhibited by the methanol extracts of the rhizomes of $A$. galanga (Rao et al., 2010), whereas the rhizome oil of $A$. officinarum and A. calcarata has shown moderate to potent antimicrobial activity against $S$. aureus and E. coli (Srividya et al., 2010). The antibacterial activity of the oil is due to a combined effect of several compounds. It relies on the hydrophobicity of the oil, which separates the lipids of the bacterial cell membrane making it more permeable. Essential oils can also inhibit the production of essential bacterial enzymes or affect the genetic material.

The main constraint against the commercialisation of essential oils is their strong flavour and high reactivity with food ingredients. This can be minimised by incorporating the oil into a carrier, which can be fabricated into a packaging film. The antibacterial activity is caused when the active compounds are released into the headspace or by contact and penetration into the food material. This further facilitates a controlled release of the active compounds over a longer time period. Chitosan films also possess antimicrobial activity. An enhanced inhibition of all three pathogens was observed when the films were enriched with oil. The inhibition was more pronounced for $S$. aureus than E. coli. The reason for the low inhibition of the growth of pathogens by the oil when incorporated into the film may be partly due to the evaporation of the oil during the drying process of the film and slow release of the oil by the film. The release of the oil from the film is affected by the thickness and moisture permeability of the film.

In conclusion, the present study revealed that the essential oil of $A$. malaccensis rhizome, as well as chitosan films enriched with the essential oil are active against the three tested microorganisms, $S$. aureus, E. coli and C. musae. Gram-positive bacteria were more sensitive to the test essential oil. The oil incorporated chitosan films had a lesser influence on the growth inhibition against the test microorganisms. This may be due to the evaporation of the essential oil during preparation of the films. However the results revealed that the increase of concentration of the essential oil in the chitosan films induced an increased percentage inhibition of the tested microorganisms. The results of this study showed the potent antimicrobial effect of chitosan films with A. malaccensis essential oil. However further investigations are needed before arriving at a firm conclusion in this regard.

\section{Acknowledgement}

This work was funded by the University of Kelaniya Research grant RP/03/02/06/03/2007.

\section{REFERENCES}

1. Abd-Elsalam K.A., Roshdy S., Amin O.E. \& Rabani M. (2010). First morphogenetic identification of the fungal pathogen Colletotrichum musae (phyllachoraceae) from imported bananas in Saudi Arabia. Genetics and Molecular Research 9(4): 2335 - 2342. DOI: http://dx.doi.org/10.4238/vol9-4gmr972 
2. Arambewela L.S.R., Arawwawala M., Owen N.L. \& Jarvis B. (2007). Volatile oil of Alpinia galanga Wild. of Sri Lanka. Journal of Essential Oil Research 19: 455 - 456.

3. Azah M.A.N., Sam Y.Y., Mailina J. \& Chua L.S.L. (2005). (E)-Methyl cinnamate: the major component of essential oils of Alpinia malaccensis var. nobilis. Journal of Tropical Forest Science 17: 631 - 633.

4. Bandara B.M.R., Hewage C.M., Jayamanne D.H.L.W., Karunaratne V., Adikaram N.K.B., Bandara K.A.N.P., Pinto M.R.M. \& Wijesundara D.S.A. (1990). Biological activity of some steam distillates from ten species of Rutaceous plants. Journal of the National Science Council of Sri Lanka 18(1): $71-77$.

5. Chien P. \& Chou C. (2006). Antifungal activity of chitosan and its application to control postharvest quality and fungal rotting of Tankan citrus fruit (Citrus tankanhayata). Journal of the Science of Food and Agriculture 86: 1964 - 1969. DOI: http://dx.doi.org/10.1002/jsfa.2570

6. de Lapeyre L. \& Mourichon X. (1998). The biology of Colletotrichum musae (Berk. et curt.) Arx and its relation to control of banana anthracnose. Acta Horticulturae 490(1): $297-304$.

DOI: http://dx.doi.org/10.17660/ActaHortic.1998.490.29

7. Han J. (2013). Innovations in Food Packaging, $2^{\text {nd }}$ edition, pp. 148 - 149. Academic Press, California, USA.

8. Hewage C.M., Bandara B.M.R., Karunaratne V., Wannigama G.P., Pinto M.R.M. \& Wijesundara D.S.A. (1998). Insecticidal activity of some medicinal plants of Sri Lanka. Journal of the National Science Council of Sri Lanka 26(1): 24 - 37.

9. Jinasena D., Pathirathna P., Wickramarachchi S. \& Marasinghe E. (2011). Effect of chitosan (unirradiated and irradiated) treatment on anthracnose disease and its potential to increase the shelf life of 'embul' banana. International Journal of Environmental Science and Development 2(4): 248 - 252. DOI: http://dx.doi.org/10.7763/IJESD.2011.V2.132

10. Krauss U., Matthews P., Bidwell R., Hocart M. \& Anthony F. (2001). Strain discrimination by fungal antagonists of Colletotrichum musae implications for bio control of crown rot of banana. Mycological Research 105(1): 67 - 76 . DOI: http://dx.doi.org/10.1017/S095375620000318X

11. Lim J., Lim T.H. \& Cha B. (2002). Isolation and identification of Colletotrichum musae from imported bananas. The Plant Pathology Journal 18(3): 161 - 164.

DOI: http://dx.doi.org/10.5423/PPJ.2002.18.3.161

12. Mehdizadeh T., Tajik H., Rohani S.M.R. \& Oromiehie A.R. (2012). Antibacterial, antioxidant and optical properties of edible starch-chitosan composite film containing Thymus kotschyanus essential oil. Veterinary Research Forum 3(3): $167-173$.

13. Ming K., Xi G.C., Ke X. \& Hyun J.P. (2010). Antimicrobial properties of chitosan and mode of action: a state of the art review. International Journal of Food Microbiology 144: $51-63$.

DOI: http://dx.doi.org/10.1016/j.ijfoodmicro.2010.09.012

14. No H.K., Meyers S.P., Prinyawiwatkul W. \& Xu Z. (2007). Applications of chitosan for improvement of quality and shelf life of foods: a review. Journal of Food Science
72(5): $87-100$.

DOI: http://dx.doi.org/10.1111/j.1750-3841.2007.00383.x

15. Ojagh S.M., Rezaei M., Razavi S.H. \& Hosseini S.M.H. (2010).

Development and evaluation of a novel biodegradable film made from chitosan and cinnamon essential oil with low affinity towards water. Journal of Food Chemistry 122: 161 - 166.

DOI: http://dx.doi.org/10.1016/j.foodchem.2010.02.033

16. Paranagama P.A. \& Ekanayake E.M.K.S. (2004). Repellent properties of essential of Alpinia calcarata ROSC against American cockroach Periplenata Americana. Journal of the National Science Foundation of Sri Lanka 32: 1 - 12.

17. Postmaster A., Kuo J., Sivasithamparam K. \& Turner D.W. (1997). Interaction between Colletotrichum musae and antagonistic microorganisms on the surface of banana leaf discs. Scientia Horticulturae 71: 113 - 125.

DOI: http://dx.doi.org/10.1016/S0304-4238(97)00080-0

18. Pripdeevech P., Nuntawong N. \& Wongpornchai S. (2009). Comparison of essential oils from the rhizomes of three Alpinia species grown in Thailand. Chemistry of Natural Compounds 45: 567 - 572.

DOI: http://dx.doi.org/10.1007/s10600-009-9367-1

19. Ranasingha L., Jayawardana B. \& Abeywickrama K. (2002). Fungicidal activity of essential oils of Cinnamomon zeylanicum (L.) and Syzygium aromaticum (L.) against crown rot and anthracnose pathogen isolated from banana. Letters in Applied Microbiology 35: 208 - 211.

DOI: http://dx.doi.org/10.1046/j.1472-765X.2002.01165.x

20. Rao K., Bhuvaneswari C., Narasu L.M. \& Giri A. (2010). Antibacterial activity of Alpinia galangal (L) wild crude extracts. Applied Biochemistry and Biotechnology 162(3): $871-884$.

DOI: http://dx.doi.org/10.1007/s12010-009-8900-9

21. Rojas-Graü M.A., Soliva-Fortuny R. \& Martín-Belloso O. (2009). Edible coatings to incorporate active ingredients to fresh-cut fruits: a review. Trends in Food Science and Technology 20(10): $438-447$.

DOI: http://dx.doi.org/10.1016/j.tifs.2009.05.002

22. Sanchez-Gonzalez L., Chafer M., Chiralt A. \& GonzalezMartinez C. (2010a). Physical properties of edible chitosan films containing bergamot essential oil and their inhibitory action on Penicillium italicum. Carbohydrate Polymers 82: $277-283$.

DOI: http://dx.doi.org/10.1016/j.carbpol.2010.04.047

23. Sánchez-González L., González-Martínez C., Chiralt A. \& Cháfer M. (2010b). Physical and antimicrobial properties of chitosan-tea tree essential oil composite films. Journal of Food Engineering 98: 443 - 452.

DOI: http://dx.doi.org/10.1016/j.jfoodeng.2010.01.026

24. Srividya A.R., Dhanabal S.P., Misra V.K. \& Suja G. (2010). Antioxidant and antimicrobial activity of Alpinia officinarum. Indian Journal of Pharmaceutical Science 72(1): 145 - 148. DOI: http://dx.doi.org/10.4103/0250-474X.62233

24. Xing Y., Li X., Xu O., Yun J., Lu Y. \& Tang Y. (2011). Effects of chitosan coating enriched with cinnamon oil on qualitative properties of sweet pepper (Capsicum annuиm L.). Journal of Food Chemistry 124: 1443 - 1450. DOI: http://dx.doi.org/10.1016/j.foodchem.2010.07.105 